\title{
The humble chest radiograph: an overlooked diagnostic modality in the COVID-19 pandemic
}

\author{
Kenneth Eng Ling Kwan ${ }^{1}$, Cher Heng $\operatorname{Tan}^{1,2} \wedge$ \\ ${ }^{1}$ Department of Diagnostic Radiology, Tan Tock Seng Hospital, Singapore, Singapore; ${ }^{2}$ Lee Kong Chian School of Medicine, Nanyang Technological \\ University, Singapore, Singapore
}

Correspondence to: Dr. Kenneth Eng Ling Kwan, MBBS, MMed, FRCR. Department of Diagnostic Radiology, Tan Tock Seng Hospital, 11, Jalan Tan Tock Seng, Singapore 308433, Singapore. Email: kenneth.el.kwan@gmail.com.

Submitted Jun 18, 2020. Accepted for publication Jul 06, 2020.

doi: 10.21037 /qims-20-771

View this article at: http://dx.doi.org/10.21037/qims-20-771

The COVID-19 pandemic is the most serious public health crisis in recent history, affecting 213 countries and territories with close to 8 million confirmed cases worldwide at the time of writing. The amount of research on the diagnosis and management of this novel disease has also grown exponentially as the number of cases surge globally.

In regard to imaging, the performance of computed tomography (CT) in the diagnosis of COVID-19 has generated the most attention, with initial studies reporting a high sensitivity that allowed it to replace the gold standard real-time reverse-transcriptase polymerase chain reaction (RT-PCR) tests (1). As such, current radiological literature on COVID-19 is dominated by CT, with scant publications available on chest radiography (CXR).

We note with interest an astute warning by your Editorin-Chief, as early as March 2020, highlighting concern that the reported high sensitivity of CT by Ai et al. (2) may only be valid in epidemic areas with high pre-test probability for this disease. In a setting of lower pre-test probability, the risk of false negative results becomes incrementally higher (3). This risk is particularly true in asymptomatic patients, who have a higher incidence of negative imaging findings, especially in the early stages of disease (4,5). Furthermore, the limited specificity of CT due to overlapping imaging features with several other viral pneumonias cannot be overemphasized (6).
The above concerns have been echoed by multiple professional bodies, which have issued guidelines against the use of CT for primary diagnosis of COVID-19. These include the American College of Radiology (7), European Society of Thoracic Imaging (8), British Society of Thoracic Imaging (9) and The Royal Australian and New Zealand College of Radiologists (10). CT is recommended for patients with worsening respiratory status to look for associated complications, such as thromboembolic disease (11).

While the CXR is not as sensitive as chest CT in the detection of COVID-19 associated lung abnormalities, it has the benefit of having lower ionizing radiation exposure while maintaining diagnostic throughput. The frequency and distribution of CXR abnormalities in COVID-19 patients has been described by Wong et al. (12), with peak severity of CXR findings at 10-12 days from symptom onset. It is prudent to note that the utility of the CXR varies in different communities, depending on the underlying public health directives and healthcare infrastructure (13). For example, in hard hit areas where patients are instructed to stay at home and to present only when symptomatic, CXRs tend to be abnormal due to the high pre-test probability. Eighty-five point seven percent of CXRs were abnormal in a cohort of COVID-19 patients from Detroit, Michigan (14), which had the third-highest number of recorded cases in the United States at the time of writing. In contrast, the CXR may be of lesser value in

^ ORCID: Kenneth Eng Ling Kwan: 0000-0001-6639-4549; Cher Heng Tan: 0000-0003-3341-3111. 
cities with aggressive testing and contact tracing, given its poor sensitivity in early and mild disease. This has been observed in Singapore; in our cohort of 109 patients, only 1 in 2 patients were eventually found to have abnormal CXRs, with only 1 in 3 overall showing abnormality at presentation (15). This may be due to (I) patients presenting early in the course of disease ( $<5$ days); (II) subtle radiographic abnormalities (typically ground-glass changes) not detected or obscured, and (III) majority of cases being mild and not progressing to pneumonia.

There are inherent challenges in performing a CT for a critically ill patient, including the need for accompanying medical personnel, mobile ventilatory support, and the physical task of transferring the patient. In these instances, the value of portability of the CXR increases. By bringing the $\mathrm{X}$-ray machine to the bedside of a COVID-19 patient, these difficulties are virtually eliminated, along with the risk of transmission during transportation en-route to the hospital's CT scanner. Such a consideration is of even greater significance in resource constrained communities where personal protective equipment is limited. In addition, portable CXR significantly reduces the risk of crossinfection by reducing the need to decontaminate the CT scanning room after each use. This also helps increase the availability of the CT scanner to other patients.

Given that CT may not be widely available, and the relative affordability and ease of acquiring a CXR, it is imperative for us to scientifically and rigorously assess its clinical utility. Unfortunately, there is currently little evidence to show that the CXR is accurate for evaluation of management. At least two groups have recently proposed quantitative scoring systems for COVID-19 pneumonia on CXRs. Toussie et al. (16) found that CXR severity score of 2 or more and obesity/morbid obesity were independent predictors of hospital admission, and a score of 3 or greater could predict the need for intubation. The CXR scoring studied by Borghesi et al. (17) identified males aged 50 years or older and females aged 80 years or older showing higher risk of severe lung disease. Its role in relation to other clinical and lab markers should also be properly assessed. In our own experience (15), we have shown that the CXR (I) parallels known markers of disease severity (like SARS) lactate dehydrogenase (LDH), C-reactive protein (CRP) and lymphocyte count, (II) severity of abnormalities correlates well with the need for supplemental oxygen, (III) may predict the need for supplemental oxygen based on quantified severity, best at D6-10, and (IV) can predict a benign clinical course when normal or with very mild abnormalities.

There is also growing interest in the role of artificial intelligence (AI) in detection of COVID-19 on CXRs. A Dutch group found that their AI system could correctly identify COVID-19 on CXRs with performance comparable to six independent readers, with a positive predictive value (PPV) of $77 \%$ (18). In our hospital, we have also recently started using AI to help identify abnormal CXRs for prompt reporting. Such systems will be helpful in communities where manpower is limited, to help triage cases and to generate reports for positive cases expeditiously.

As this is likely to be a long-drawn pandemic, we urge the medical community to place greater attention on scientifically assessing the role of CXR as a triage and monitoring tool of COVID-19.

\section{Acknowledgments}

Funding: None.

\section{Footnote}

Conflicts of Interest: Both authors have completed the ICMJE uniform disclosure form (available at http://dx.doi. org/10.21037/qims-20-771). The authors have no conflicts of interest to declare.

Open Access Statement: This is an Open Access article distributed in accordance with the Creative Commons Attribution-NonCommercial-NoDerivs 4.0 International License (CC BY-NC-ND 4.0), which permits the noncommercial replication and distribution of the article with the strict proviso that no changes or edits are made and the original work is properly cited (including links to both the formal publication through the relevant DOI and the license). See: https://creativecommons.org/licenses/by-nc-nd/4.0/.

\section{References}

1. Yang Q, Liu Q, Xu H, Lu H, Liu S, Li H. Imaging of coronavirus disease 2019: A Chinese expert consensus statement. Eur J Radiol 2020;127:109008.

2. Ai T, Yang Z, Hou H, Zhan C, Chen C, Lv W, Tao Q, Sun Z, Xia L. Correlation of Chest CT and RT-PCR Testing 
in Coronavirus Disease 2019 (COVID-19) in China: A

Report of 1014 Cases. Radiology 2020;296:E32-40.

3. Woloshin S, Patel N, Kesselheim AS. False Negative Tests for SARS-CoV-2 Infection - Challenges and Implications. N Engl J Med 2020. [Epub ahead of print]. doi:10.1056/ NEJMp2015897.

4. Zeng Y, Fu J, Yu X, Huang Z, Yin X, Geng D, Zhang J. Should computed tomography (CT) be used as a screening or follow-up tool for asymptomatic patients with SARS-CoV-2 infection? Quant Imaging Med Surg 2020;10:1150-2.

5. Xu C, Xu Q, Du C, Li J, Hu Z, Yi Y. Radiological followup of twelve COVID-19 patients with initially normal chest CT. Quant Imaging Med Surg 2020;10:1153-7.

6. Wáng YXJ. A call for caution in extrapolating chest CT sensitivity for COVID-19 derived from hospital data to patients among general population. Quant Imaging Med Surg 2020;10:798-9.

7. American College of Radiology. ACR Recommendations for the use of Chest Radiography and Computed Tomography (CT) for Suspected COVID-19 Infection. 22 March 2020 ed. Available online: https://www.acr.org/ Advocacy-and-Economics/ACR-Position-Statements/ Recommendations-for-Chest-Radiography-and-CTfor-Suspected-COVID19-Infection2020. Accessed 17 May 2020.

8. Revel MP, Parkar AP, Prosch H, Silva M, Sverzellati N, Gleeson F, Brady A. COVID-19 patients and the radiology department - advice from the European Society of Radiology (ESR) and the European Society of Thoracic Imaging (ESTI). Eur Radiol 2020. [Epub ahead of print]. doi:10.1007/s00330-020-06865-y.

9. British Society of Thoracic Imaging. COVID-19 British Society of Thoracic Imaging Statement and Guidance. 11 March 2020 ed. Available online: https://www.bsti.org.uk/ standards-clinical-guidelines/clinical-guidelines/covid-19bsti-statement-and-guidance/2020. Accessed 17 May 2020.

10. The Royal Australian and New Zealand College of Radiologists. Advice on appropriate use of CT throughout the COVID-19 pandemic. 20 April 2020 ed. Available online: https://www.ranzcr.com/our-work/coronavirus/ position-statements-and-guidance2020. Accessed 17 May 2020.

11. Bikdeli B, Madhavan MV, Jimenez D, Chuich T, Dreyfus I, Driggin E, Nigoghossian C, Ageno W, Madjid M, Guo Y, Tang LV, Hu Y, Giri J, Cushman M, Quéré I, Dimakakos
EP, Gibson CM, Lippi G, Favaloro EJ, Fareed J, Caprini JA, Tafur AJ, Burton JR, Francese DP, Wang EY, Falanga A, McLintock C, Hunt BJ, Spyropoulos AC, Barnes GD, Eikelboom JW, Weinberg I, Schulman S, Carrier M, Piazza G, Beckman JA, Steg PG, Stone GW, Rosenkranz S, Goldhaber SZ, Parikh SA, Monreal M, Krumholz HM, Konstantinides SV, Weitz JI, Lip GYH. COVID-19 and Thrombotic or Thromboembolic Disease: Implications for Prevention, Antithrombotic Therapy, and FollowUp: JACC State-of-the-Art Review. J Am Coll Cardiol 2020;75:2950-73.

12. Wong HYF, Lam HYS, Fong AH, Leung ST, Chin TW, Lo CSY, Lui MM, Lee JCY, Chiu KW, Chung T, Lee EYP, Wan EYF, Hung FNI, Lam TPW, Kuo M, Ng MY. Frequency and Distribution of Chest Radiographic Findings in COVID-19 Positive Patients. Radiology 2020;296:E72-8.

13. Rubin GD, Ryerson CJ, Haramati LB, Sverzellati N, Kanne JP, Raoof S, Schluger NW, Volpi A, Yim JJ, Martin IBK, Anderson DJ, Kong C, Altes T, Bush A, Desai SR, Goldin J, Goo JM, Humbert M, Inoue Y, Kauczor HU, Luo F, Mazzone PJ, Prokop M, Remy-Jardin M, Richeldi L, Schaefer-Prokop CM, Tomiyama N, Wells AU, Leung AN. The Role of Chest Imaging in Patient Management during the COVID-19 Pandemic: A Multinational Consensus Statement from the Fleischner Society. Chest 2020;158:106-16.

14. Pakray A, Walker D, Figacz A, Kilanowski S, Rhodes C, Doshi S, Coffey M. Imaging evaluation of COVID-19 in the emergency department. Emerg Radiol 2020. [Epub ahead of print]. doi:10.1007/s10140-020-01787-0.

15. Hui TCH, Khoo HW, Young BE, Haja Mohideen SM, Lee YS, Lim CJ, Leo YS, Kaw GJL, Lye DC, Tan CH. Clinical utility of chest radiography for severe COVID-19. Quant Imaging Med Surg 2020;10:1540-50.

16. Toussie D, Voutsinas N, Finkelstein M, Cedillo MA, Manna S, Maron SZ, Jacobi A, Chung M, Bernheim A, Eber C, Concepcion J, Fayad Z, Gupta YS. Clinical and Chest Radiography Features Determine Patient Outcomes In Young and Middle Age Adults with COVID-19. Radiology 2020. [Epub ahead of print]. doi:10.1148/ radiol.2020201754.

17. Borghesi A, Zigliani A, Masciullo R, Golemi S, Maculotti P, Farina D, Maroldi R. Radiographic severity index in COVID-19 pneumonia: relationship to age and sex in 783 Italian patients. Radiol Med 2020;125:461-4. 
18. Murphy K, Smits H, Knoops AJG, Korst MBJM, Samson T, Scholten ET, Schalekamp S, Schaefer-Prokop CM, Philipsen RHHM, Meijers A, Melendez J, van Ginneken B,
Rutten M. COVID-19 on the Chest Radiograph: A MultiReader Evaluation of an AI System. Radiology 2020. [Epub ahead of print]. doi:10.1148/radiol.2020201874.

Cite this article as: Kwan KEL, Tan CH. The humble chest radiograph: an overlooked diagnostic modality in the COVID-19 pandemic. Quant Imaging Med Surg 2020;10(9):18871890. doi: $10.21037 /$ qims-20-771 